\title{
TERROR MANAGEMENT AFTER A RECENT SUICIDE ATTEMPT
}

\author{
Ksenia A. Chistopolskaya, \\ Moscow Research Institute of Psychiatry \\ Moscow, Russia \\ Sergey N. Enikolopov \\ Mental Health Research Center, \\ Russian Academy of Medical Sciences \\ Moscow, Russia
}

Suicide is a controversial phenomenon that people of different cultures and even of different epochs have had difficulty naming. It used to be an enduring theme of many medical, psychological, philosophical, and moralistic discussions. It is a paradoxical act of ultimate self-destruction, a flight from life to death. To commit suicide is to overcome the fear of personal death and to make a step into nothingness. Such a desperately brave deed requires an abandonment of one's sense of immortality, which we all have, a change of values and worldviews. But if one's suicide attempt proves unsuccessful, the question becomes how to explain to oneself and others one's recent act of self-violence. To discover these explanations, we conducted a study of 319 people, ranging in age from 18 to 25 ; they were all either students $(n=156)$ or patients in an emergency toxicology ward (people who had attempted to poison themselves, $n=163$ ). This article summarizes theories of suicidal behavior and of the fear of death together with the ideas of cultural anthropologist E. Becker on these matters and puts suicide into the terror-management perspective. The suicidal act is viewed as a mortality salience, and the hypothesis is that people who deny their recent suicide attempt $(n=33)$ and who have one $(n$ $=95)$ or several $(n=35)$ suicide attempts in their personal history exhibit different terror-management patterns in comparison with each other and with the control group. They fall back on different resources with various degrees of effectiveness. Implications of these results for understanding suicidal and postsuicidal behavior are discussed and suggestions for rehabilitation are made.

Keywords: terror management, mortality salience, fear of death, suicide attempt, causa sui project, hardiness. 


\section{Definitions of Suicide}

If we search for the meaning of the word suicide in classical Greek,

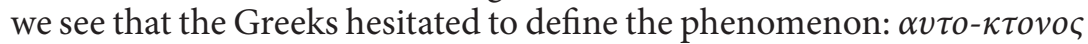
(the term used by Aeschylus and Euripides) meant "mutual murder," "killing the friendly," "kill with one's own hands"; the word $\alpha v \tau o-\chi \varepsilon\llcorner\rho o \varsigma$ (from the works of Sophocles, Plato, Democritus, Plutarch) was used for "done with one's own hands," "the guilty," "killer," "personally committed murder." The word $\alpha v \tau o-\vartheta \alpha v \alpha \tau o \varsigma$ was also used for people who call death on themselves, seek death-for example, on the battlefield (Dvoretsky, 1958). In classical Latin it was called mors voluntaria (voluntary death), to commit suicide was sibi mortem consciscere (voluntarily choose one's own death), so the free will in the act was stressed (Littlejohn, 2003).

The contemporary word suicide was derived from the Latin suicidium, a scientific term, which emerged presumably in the seventeenth century (Littlejohn, 2003). This neologism was created by combining the reflexive pronoun sui, "self," and the verb caedere, "to strike," "to cut," "to kill," "to stab," "to sacrifice," "to break" (Tananushko, 2005). The word suicide was first used by Sir Thomas Brown in his Religio Medici (1635); in Germany and in France this term appeared a century later. Before the introduction of the word, other terms, mostly circumlocutions and euphemisms relating to self-murder, were used; among them were "selfdestruction," "self-killing," "self-slaughter," sibi mortem consciscere, "to decide about death for oneself," vim sibi inferre, "to cause violence to oneself", and sui manu cadere, "to fall by one's own hand", as well as the word autoch(e)iria, Greek $\alpha v \tau o-\chi \varepsilon \iota \rho o \varsigma$, which many authors took into their works in New Latin (Shneidman, 1976).

Starting in the eighteenth century, certain medical papers openly declared the connection between suicide and madness or suicide and melancholy. For example, Christoph Wilhelm Hufeland described melancholia suicidium, Francois Boissier de Sauvages mentioned melancholia anglica, Philippe Pinel wrote about melancholy with a proneness to suicide (Leenaars, 1993).

In the nineteenth century the psychiatrist Jean-Etienne Esquirol stated, "Suicide shows all the characteristics of mental alienation" (1838, vol. 1, p. 639), and "a man attempts self-destruction only in delirium and suicides are mentally alienated" (vol. 1, p. 665). He believed that suicide 
is "only a phenomenon resulting from many different causes and appearing under many different forms; and it is clear that this phenomenon is not characteristic of a disease" (vol. 1, p. 528), thus regarding it as a nonspecific symptom. His disciple Jean-Pierre Falret studied the connection between suicide and hypochondria and included suicidal behavior in the manic-depressive syndrome, a psychiatric illness that he discovered and described (Falret, 1864). Emile Durkheim criticized these medical practioners, for they used the term suicide in its narrow sense and refused to consider suicidal a person who "willingly sacrifices his life in obedience to the laws, to keep pledged faith, for his country's safety" (Durkheim, 1979 , p. 66). Durkheim returned this phenomenon to the social realm when he described egoistic (excessive individuation), anomic (social alienation, lack of social direction), and altruistic (predominance of group values, goals, and beliefs) suicides.

From the perspective of psychoanalysis, suicide may be viewed as an "acting out," when a person takes a risk to limit his life. Staying in the psychological realm, in 1910 Sigmund Freud declared that "suicide is murder turned around 180 degrees" (as put by Leenaars, 1993, p. 126). In his paper Mourning and Melancholia (1917/1984) Freud suggested that depression and suicide may be understood as an expression of anger toward an introjected, ambivalent, lost object (in the process of separation-individuation). He again addressed two social evils in the work Civilization and its Discontents (1929/2002). Freud argued that suicide and war are different aspects of a unitary problem, the expressions in human beings of instinctual aggression and instinctual destruction, which in turn represent the death instinct ). Karl Menninger noted that the wish of suicide consists of the wish to die, to kill and to kill oneself (1938).

Edwin Shneidman, the famous American suicidologist, defined suicide as a cessation of the continuity of the self: "Suicide is a human act of self-intentioned, self-inflicted cessation, (Shneidman, 1976, p. 5) an act of life that can lead to death (whatever were the fantasies, forms, attitudes, games of life and death-risky behavior). Jean-Pierre Soubrier, his disciple, specified that "suicide is a final act of despair of which the result is not known, occurring after a battle between the unconscious death wish and a desire to live better, to love and be loved" (Soubrier, 1993, p. 37). He emphasized the paradoxical nature of the suicidal act: the wish of the person to change his life for the better through death. The scientist 
concluded that specialists may see an alternative to ultimate destruction if they focus their attention on the frustrated needs of the suicidal.

The Russian suicidologist A.G. Ambrumova welcomed this framework and also noticed the "paradoxically positive evaluation of death" by suicidals (Ambrumova \& Kalashnikova, 1998, p. 65). But many authors have pointed out the ambivalence of suicidals: they are both attracted to and repelled by death (Poeldinger, 1968; Sokolova, 1989).

Nowadays in the Western world suicide is described as a "conscious act of self-induced annihilation, best understood as a multidimensional malaise in a needful individual who defines an issue for which the suicide is perceived as a best solution" (Soubrier, 1993, p. 38). The World Health Organization has stated that suicide is "the result of an act, deliberately initiated and performed by a person in the full knowledge or expectation of its fatal outcome" (Murthy, 2001, p. 37).

\section{The Problem of the Fear of Death}

Western scientists started to show interest in the topic of death in the 1970s for two reasons. First, society grew skeptical of religion and needed to comprehend human existence within the limits of life. Second, both laypeople and professionals noticed a change in attitudes toward death. Previously death was considered as one of the cycles of life, and neglect of the dying was uncommon. People died at home, and the rules of caring for the moribund and the social rituals concerning death were well known. But with the emergence of nursing homes and the funeral business these practices started to fade. People were dying alone, cared for by nurses and specialists, but not by family and friends. Death was equated with separation, loneliness, abandonment (Shneidman, 1973).

However, the war in Vietnam, memories of the Second World War, the threat of an atomic holocaust, and great ambitions in politics in a general atmosphere of instability and tough competition made people to give the problem of death a second thought. Some scientists started to wonder whether immortality was possible, both symbolically and literally, to build utopias and dystopias, to ponder on the individual experience of immortality in culture and the general feeling of invincibility. Robert Lifton wrote, "Even in our unconscious lives we are by no means convinced of our own immortality... We both 'know' that we will die, and resist and fail to act upon that knowledge. Nor is the need to tran- 
scend death mere denial. More essentially, it represents a compelling universal urge to maintain an inner sense of continuous symbolic relationship, over time and space, with the various elements of life... a sense of immortality as in itself neither compensatory nor pathological, but as humanity's symbolization of ties with both biological fellows and history, past and future" (Lifton, 1977, p. 277). Lifton compared this feeling of immortality with Erik Erikson's (2000) concept of "basic trust." In his view immortality can be achieved in five ways: (1) biological - in one's own children; (2) theological - as a belief in an afterlife; (3) through creativity - in achievements of enduring human impact; (4) through eternal nature; and (5) through experiential transcendence, the "continuous present," which can be equated with eternity or with "mythical time" (Eliade, 1958). The loss of immortality, or impaired death imagery, is characterized by (1) death anxiety (manifested in war neurosis, guilt over survival); (2) psychic numbing (the constant restriction of life because of the fear of death, "If I feel nothing, then death doesn't exist," a shrinking of the ego, and a diminished capacity for experience); (3) suspicion of counterfeit nurturance ("If death exists, then life is counterfeit").

\section{The Fear of Death and Aggression}

Cultural anthropologist Ernest Becker (1924-1974) needed the construct of death for his model of a moral society (Becker, 1968). At first he stated that death is the ultimate evil and that humans are the only animals that await their death. People build their individual symbolic projects (causa sui) because symbols are infinite and body is finite and reminds of death. People sacrifice their physical existence in exchange for symbolic immortality (Becker, 1973).

Ernest Becker agreed with Gregory Zilboorg that the fear of death is always present in our mental functioning. This fear is an expression of the instinct for self-preservation, which functions as a constant drive to maintain life and to master the dangers that threaten life: "Such constant expenditure of psychological energy on the business of preserving life would be impossible if the fear of death were not as constant. The very term 'self-preservation' implies an effort against some force of disintegration; the affective aspect of this is fear, fear of death" (Zilboorg, 1943, p. 467). 
People use each other to state their personal victory over death. Becker quoted Otto Rank: "The death fear of the ego is lessened by the killing, the sacrifice, of the other; through the death of the other, one buys oneself free from the penalty of dying, of being killed" (Rank, 1936, p. 116) and recalled the position of Freud on the matter: "Freud saw that when it comes to enemies and strangers, the ego can consign them to the limbo of death without even a second thought" (Becker, 1975, p. 109). Freud actually said, "In our unconscious we daily and hourly deport all who stand in our way, all who have offended or injured us" (Freud, $1915 / 1959$, p. 314). That is why heroes are so unique. Becker (1975, p. 109) writes:

We admire him [the hero] precisely because he is willing to give his life for others instead of taking theirs for his. Heroism is an unusual reversal of routine values, and it is another thing that makes war so uplifting, as mankind has long known: war is a ritual for the emergence of heroes, and so for the transmutation of common, selfish values. In war men live their own ennoblement. But what we are reluctant to admit is that the admiration of the hero is a vicarious catharsis of our own fears, fears that are deeply hidden; and this is what plunges us into uncritical hero worship: what the hero does seems so superlative to us.

Becker analyzed various religious systems of primitive and contemporary societies on the basis of how well they defended people from the fear of death. He liked the model of tribal society best, but before the chief became the embodiment of god on earth. When the divine was placed in the realm of the visible, it led to an imbalance of power, which devalued the lives of common people (in some societies they even were deprived of souls). A new need had arisen: leaders had to constantly prove their immortality, and they did so primarily through killing their enemies (Aristotle's insight - "luck is when the arrow hits the fellow next to you" - was frequently quoted by Becker). Becker thought that Christianity tried to bring about a return to primitive equality, but the attempt was just partially successful.

One finds the ideology of immortality in physical parenthood, when the child becomes the spiritual property of a family without rights of personal choice. Money, which leads to the accumulation of goods, is another form of overcoming the fear of death. Coins first appeared in religious cults and still bear divine connotations. In a "one-dimensional," atheistic 
society people unconsciously continue to draw on those many means of achieving immortality in order to escape their awareness of their mortal nature. Becker believed that one needs some system of meanings or a worldview that includes the realm of the transcendental, but it has to be critical, sensitive to the frailty of life in the present.

As we see, Becker was highly censorious of the feeling of immortality. Lifton considered it obligatory and healthy, but Becker pointed out many of its morbid weaknesses. He warned that the pursuit of immortality - or causa sui (self-esteem) - may lead to tragedies and injustices, that people have to live with a constant feeling of the frailty of their being, in permanent awe of creation.

\section{Studies of the Fear of Death}

The ideas of Becker are continued in terror-management theory, proposed in 1986 by Jeff Greenberg, Tom Pyszczynski, and Sheldon Solomon. They state that most of human behavior can be understood as an attempt to achieve psychological equanimity in the face of mortality. People gain this equanimity through culture, which raises them above other animals (Goldenberg et al., 2001). The cultural anxiety buffer consists of (a) belief in one's cultural worldview and (b) self-esteem, which is derived from living up to the standards of that worldview (Pyszczynski, Greenberg, Solomon, Arndt, \& Schimel, 2004). In defense of their feelings of personal value and their worldviews people are prone to risk their lives (for example, to drive recklessly), to have negative feelings toward opponents, to prefer authoritarian leaders, to demand tough sentencing for relatively minor faults and crimes (Harmon-Jones, Greenberg, Solomon, \& Simon, 1996; Hirschberger, 2006).

But other defenses have less of a negative effect. First, there are attachment relationships: people choose them and as a result give up their worldviews and self-esteem. Such a compromise has its emotional price: the choice is accompanied by a reduced feeling of pride and an intensification of guilt and shame (Mikulincer, Florian, \& Hirschberger, 2003).

Second, there is nostalgia. C. Sedikides with colleagues (Sedikides, Wildshut, Routledge, \& Arndt, 2008; Wildshut, Sedikides, Arndt, \& Routledge, 2006) defined nostalgia as a self-relevant, primarily positive emotion with some "bittersweet" elements. People recall their loved and 
close ones, social contexts as a whole, places, objects, events. The authors prove that nostalgia repairs discontinuity of the self, binds the past and the present. Their studies show that people restore their individual and collective selves by reminiscing about their past when they lack resources to deal with the situation in the present.

C. Routledge and colleagues (Routledge, Arndt, \& Sheldon, 2004) studied creativity from the terror-management perspective. They have shown that creativity lessens the fear of death after mortality is made salient, so creative people don't need to defend themselves with the help of their worldviews. But defense from the fear of death through creativity also has its weak point: as in the case of attachment relationships it may increase the feeling of guilt. Being an instrument of individuation, creativity becomes problematic when a person doesn't have a safe basis in assimilation with other people.

A bit later Paul T. Wong formulated the meaning-management theory, in which attitudes toward life and death are connected like communicating vessels (2007). He believes that people who fear death and try to avoid any reminders of it in their daily life are extremely attached to life. People who are in difficult life circumstances or who are terminally ill accept death as an escape and even welcome it, or death just seems more attractive to them than life. Wong proposes that the most "healthy" and benign attitude to death is neutral, when one sees it as a natural and unavoidable phenomenon.

\section{The Fear of Death and Suicide}

Becker viewed suicidal behavior as a form of coping with the fear of death. He wrote (1968, p. 248):

One opens one's veins, Roman-style, or one's stomach, samurai-style, when one has already had the experiences of being a locus of control over a rich meaningful world. Life is ended with the dignity with which it has been lived. In modern society, suicide... is often the last resort that an individual has, to unify esthetically a life that has failed. In this sense, suicide always offers man a potential for meaningful self-realization, even if only as a saving grace, a desperate artistic resort... The main difference from the samurai, of course, is that the samurai's suicide reflects a network of broad social obligations, a life that has always fit into a transcending scheme of things. It is 
logically integral to a life lived, as a work of art, and not merely a last minute ingenuity to salvage a bankrupt existence. It is Socrates, again, who comes to mind as the model for this kind of integral suicide.

Becker believed that any growth crisis comes with a threat of suicide. Thus, he considered a suicidal person a hero, the one who experiences the terror of death vividly and tries to break away from the lies of his character in order to find himself (or to preserve himself in a controversial social situation).

\section{Research}

We conducted our research in order to clarify attitudes to death and patterns of defenses in people after suicide attempts (Chistopolskaya, 2010; Chistopolskaya, Enikolopov, Badaljan, \& Sarkisov, in press). We hypothesized that a suicide attempt acts as a strong mortality salience, from which people need to defend themselves. The impact of this salience corresponds to the intensity of the suicidal intent and the suicidal experience. It further influences the pattern of defenses.

\section{Participants}

A total of 319 young people (ranging in age from 18 to 25) participated in the study. The control group consisted of 156 undergraduate students (40 males, 116 females) at the State University of Management (departments of psychology, sociology, and management). The experimental group (163 people, 41 males and 122 females) consisted of patients in the department of toxicology at the N. V. Sklifosovsky Research Institute of Emergency Medicine. All of them had recently (in the past 2 to 14 days) tried to poison themselves. Thirty-three had made two or more suicide attempts, 95 had made one attempt, and 35 denied recent suicidal thoughts and actions (they explained the acts as "accidents" or that they "just wanted to frighten somebody", regardless of the severity of the medical consequences).

\section{Materials and Procedure}

Students filled out the materials during a regular class meeting on a voluntary basis. Patients were interviewed personally and received feedback via e-mail when they requested it. 
The Death-Attitude Profile-Revised (DAP-R) (Wong, Reker, \& Gesser, 1994) consists of 32 items rated on a 7-point scale from 1 (strongly disagree) to 7 (strongly agree). The adaptation of the DAP-R was done by us for the same 156 students. We found that all the five original scales had high internal validity (fear of death, 7 items, $\alpha=.82$; death avoidance, 5 items, $\alpha=.89$; neutral acceptance, 5 items, $\alpha=.72$; approach acceptance, 10 items, $\alpha=.84$; escape acceptance, 5 items, $\alpha=.82$ ).

The Fear of Personal Death Scale (Mikulincer \& Florian, 2007) in our adaptation consists of 30 items rated on a 7-point scale. We found a somewhat different structure of the inventory than it was in the original. We received 3 scales in the intrapersonal dimension (fear of the consequences of death for personality, 11 items, $\alpha=.92$; for aspirations, 8 items, $\alpha=.91$, for body, 5 items, $\alpha=.87$ ), 2 scales in the interpersonal dimension (for family and friends, 4 items, $\alpha=.84$; for social identity (fear of oblivion), 3 items, $\alpha=.69$ ), and 1 scale in the transpersonal dimension (fear of transcendental consequences, 4 items, $\alpha=.89$ ).

We also used our adaptation of the death access measures by Jamie Arndt (Arndt, Greenberg, Solomon, Pyszczynsky, \& Simon, 1997). These are 25 puzzles with the possibility of filling in seven death-oriented (or neutral) words.

To ascertain patterns of defenses and attitudes to life we used the Zimbardo Time Perspective Inventory (Zimbardo \& Boyd, 1999) in a Russian adaptation (Sircova \& Mitina, 2008) with 56 items rated from 1 (strongly disagree) to 5 (strongly agree), and the Hardiness Survey by Maddi (2004) in a Russian adaptation (Leontiev \& Rasskazova, 2006) with 45 items rated from 1 (no) to 4 (yes).

Statistical calculations were made in the program SPSS 11.0: factor analysis (method of principal components, varimax), Cronbach's alpha coefficient, Pearson's correlation analysis, and the Mann-Whitney U-test.

\section{Results}

We found that the fear of death was much stronger in people who admitted that they had made one suicide attempt (95 subjects) than in the control sample. The Mann-Whitney U-test showed that those suicidals feared and avoided death (fear of death, $p=.004$; fear of the consequences for personality, $p<.001$; for body, $p<.001$; for aspirations, $p=.003$; for friends and family, $p=.027$; for social identity, $p<.001$; 
death avoidance, $p<.001)$. Their fear of the consequences for body correlated with negative past $(r=.33, p<.01)$ and fatalistic present $(r=.37$, $p<.01)$; their future scale correlated with fear of the consequences for personality $(r=.30, p<.01)$, aspirations $(r=.24, p<.05)$, and significant others $(r=.30, p<.01)$.

People who denied their attempt (35 subjects) were also afraid of death, but they differed significantly from the control sample just on the scales of fear of the consequences for personality $(p=.016)$ and body $(p=.018)$. Their defense was shown mostly in death avoidance $(p<.001)$. Their fear of death was connected with positive past $(r=.57$, $p<.01)$ - that is, it fulfilled its defensive function. Positive past also correlated with fear of the consequences for personality $(r=.66, p<.01)$, aspirations $(r=.60, p<.01)$, and significant others $(r=.44, p<.01)$, and with fear of transcendental consequences $(r=.47, p<.01)$. In other words, these people drew on the feeling of nostalgia, and it alleviated their fears.

People from both these samples refused to believe in an afterlife and scored $p<.001$ (group with one attempt), $p=.004$ (group with denial of attempt) in comparison with the control sample. They avoided death words in the death access measure ( $p=.042$ for the group with denial of attempt, $p<.001$ for the group with one attempt). In addition, the group with one suicide attempt showed lower neutral death acceptance in comparison with the controls $(p=.003)$.

People with several suicide attempts didn't fear death; they accepted it as a way to escape from the vicissitudes of life ( $p=.001)$, but, in comparison with the controls, they strongly feared oblivion $(p<.001)$. Their death avoidance and fear of the consequences for body were negatively correlated with past negative $(r=-.42, p<.05 ; r=-.35, p<.05)$, which scored high. Their past negative and present fatalistic were positively correlated with escape acceptance $(r=.40, p<.05 ; r=.55, p<.01)$. Interestingly, their future scale correlated with fear of the consequences for personality, aspirations, and significant others $(r=.35, p<.05 ; r=.24$, $p<.05 ; r=.48, p<.01$ ), their past positive correlated with fear of the consequences for body, aspirations, and significant others $(r=.47, p<.01$; $r=.43, p<.05 ; r=.40, p<.05)$, and their hedonistic present correlated with fear of transcendental consequences $(r=.37, p<.05)$; but positive time perspective in this group was very low, as were the fears themselves. 
Those who admitted to having made one or several attempts had negative correlations between escape acceptance and hardiness.

This study has shown that the fear of death serves as a defense against suicidal behavior, but at the same time it is a painful experience, which, in its turn, calls for a defense. Feelings of nostalgia, warm remembrances of one's childhood, allow one to cope with the task the best, but they plunge the person into illusions and make one deny reality. The future, the ability to work for some far-reaching goals, the formation of one's causa sui project, as Becker would put it, is a more fragile defense, so it leaves one with the awareness of one's finitude. Cultural defenses - literal immortality (religion, belief in an afterlife) (Dechesne et al., 2003; Wong, 2007), rationalization (neutral acceptance of death as a natural phenomenon) (Wong, 2007) - don't work for suicidal people. A positive attitude toward death, as Ambrumova has put it (Ambrumova \& Kalashnikova, 1998), is seen in people with several suicide attempts - as their established style of coping with the fear of death. Notably, these suicidals combine the fear of death with past positive, present hedonistic, and future time perspectives, which give them an appreciation for life, but they score equally low on them. Escape acceptance lets them build an alternative worldview, which is desirable, but it is nonexistent. It is another type of flight from reality.

\section{Conclusion}

Different epochs have brought into existence different attitudes toward suicidal behavior: it has been considered as an act of courage, as a crime, and as an illness; but all these views could be possible for just one reason: through this deed one overcomes the main fear - the fear of death. Terror-management theory and the works of Becker give us a clue to understanding this phenomenon. Becker wrote that a person is doomed to fear death; it is hardwired in the very condition of existence. This curse (or this gift) was received with the "forbidden fruit" - cognition (or knowledge of good and evil). Becker (1973), after Kierkegaard (1843/1993), recalled the story of the Fall. It proves to be our instrument of survival, the feeling that gives us an appreciation for life, and we have to learn how to use it both in daily life and in crisis situations. 


\section{References}

Ambrumova, A.G., \& Kalashnikova, O.E. (1998). Kliniko-psihologicheskie aspekty samoubijstva [Clinical and psychological aspects of suicide]. Socialnaya $i$ klinicheskaya psihiatriya [Social and Clinical Psychiatry], 8(4), 65-77.

Arndt, J., Greenberg, J., Solomon, S., Pyszczynsky, T., \& Simon, L. (1997) Suppression, accessibility of death related thoughts, and cultural worldview defense: exploring the psychodynamics of terror management. Journal of Personality and Social Psychology, 73, 1, 5-18.

Becker, E. (1968). The structure of evil: An essay on the unification of the science of man. New York: Braziller.

Becker, E. (1973). The denial of death. New York: Free Press.

Becker, E. (1975). Escape from evil. New York: Free Press.

Chistopolskaya, K.A. (2010). Adaptacija na russkojazychnoj vyborke metodik issledovanija otnoshenij $\mathrm{k}$ smerti i strahov smerti [Russian adaptation of measures of attitudes to death and death fears]. Praktichna psihologija ta social'na robota [Practical Psychology and Social Work], 9, 73-77.

Chistopolskaya, K.A., Enikolopov, S.N., Badaljan, A.V., \& Sarkisov, S.A. (in press). Adaptacija metodik issledovanija otnoshenij $\mathrm{k}$ smerti u ljudej v ostrom postsuicide i v otnositel'nom psihologicheskom blagopoluchii [Adaptation of death attitude measures on people in acute postsuicide and in relative psychological well-being]. Social'naja $i$ klinicheskaja psihiatrija [Social and Clinical Psychiatry].

Dechesne, M., Pyszczynski, T., Arndt, J., Ransom, S., Sheldon, K., van Knippenberg, A., \& Janssen, J. (2003). Literal and symbolic immortality: The effect of evidence of literal immortality on self-esteem striving in response to mortality salience. Journal of Personality and Social Psychology, 84(4), 722-737.

Durkheim, E. (1979). Suicide: A study in sociology. New York: Free Press.

Dvoretsky, I.H. (1958). Drevnegrechesko-russkiy slovar' [Classical Greek-Russian dictionary]. Ed. S.I. Sobolevsky. Moscow: Governmental publishing house of foreign and national dictionaries.

Eliade, M. (1958). Patterns in comparative religion. New York: Sheed \& Ward.

Erikson, E. (2000). Detstvo i obschestvo [Childhood and society]. St Petersburg: Letnij sad.

Esquirol, J.-E. (1838). Des maladies mentales. Brussels.

Falret, J-P. (1864). Des maladies mentales et des asiles d'alienes. Paris.

Freud, S. (1959). Thoughts for the times on war and death. In J. Strachey (Ed. \& Trans.), The standard edition of the complete psychological works of Sigmund Freud (Vol. 4, pp. 288-317). London: Hogarth Press. (Original work published 1915). 
Freud, S. (1984). Pechal' i melanholija [Mourning and melancholia]. In V.K. Vilunas \& Y. B. Gippenreiter (Eds.), Psihologia emocij: Texty [Psychology of emotions: Texts] (pp. 203-211). Moscow: Moscow State University. (Original work published 1917).

Freud, S. (2002). Civilization and its discontents. London: Penguin (Original work published 1929).

Goldenberg, J.M., Pyszczynski, T., Greenberg, J., Solomon, S., Kluck, B., \& Cornwell, R. (2001). I am not an animal: Mortality salience, disgust and the denial of human creatureliness. Journal of Experimental Psychology, 130(3), 427-435.

Greenberg, J., Pyszczynski, T., \& Solomon, S. (1986). The causes and consequences of a need for self-esteem: A terror management theory. In R.F. Baumeister (Ed.), Public self and private self (pp. 189-212). New York: Springer-Verlag.

Harmon-Jones, E., Greenberg, J., Solomon, S., \& Simon, L. (1996). The effects of mortality salience on intergroup bias between minimal groups. European Journal of Social Psychology, 25, 781-785.

Hirschberger, G. (2006). Terror management and attributions of blame to innocent victims: Reconciling compassionate and defensive responses. Journal of Personality and Social Psychology, 91(5), 832-844.

Kierkegaard, S. (1993). Strah i trepet [Fear and trembling]. Moscow: Respublika. (Original work published 1843).

Leenaars, A.A. (1993). Unconscious processes. In A.A. Leenaars (Ed.), Suicidology: Essays in honor of Edwin S. Shneidman (pp. 125-147). Northvale, NJ: Aronson.

Leontiev, D.A., \& Rasskazova, E.I. (2006). Test zhiznestojkosti [Hardiness Survey]. Moscow: Smysl.

Lifton, R. (1977). The sense of immortality: On death and the continuity of life. In H. Feifel (Ed.), New meanings of death (pp. 273-290). New York: McGraw-Hill.

Littlejohn, J. (2003). Collins Latin dictionary plus grammar. New York: HarperCollins.

Maddi, S. (2004) Hardiness: An operationalization of existential courage. Journal of Humanistic Psychology, 44(3), 279-298.

Menninger, K. (1938). Man against himself. New York: Harcourt Brace.

Mikulincer, M., \& Florian, V. (2007). The complex and multifaceted nature of the fear of personal death: The multidimensional model of Victor Florian. In A. Tomer, G.T. Eliason, \& P.T. Wong (Eds.), Existential and spiritual issues in death attitudes (pp. 39-63). New York: Erlbaum.

Mikulincer, M., Florian, V., \& Hirschberger G. (2003). The existential function of close relationships: Introducing death into the science of love. Personality and Social Psychology Review, 7, 20-40.

Murthy, R.S. (Ed.). (2001). The World health report 2001: Mental health: New understanding, new hope. Geneva: World Health Organization. 
Poeldinger, W. (1968). Die Abschaetzung der Suizidalitaet. Eine medizinisch-psychologische und medizinisch-soziologische Studie. Stuttgart: Huber.

Pyszczynski, T., Greenberg, J., Solomon, S., Arndt, J., \& Schimel, J. (2004). Why do people need self-esteem? A theoretical and empirical review. Psychological Bulletin, 130, 435-468.

Rank, O. (1936) Will therapy: An analysis of the therapeutic process in terms of relationship. New York: Knopf.

Routledge, C., Arndt, J., \& Sheldon, K.M. (2004). Task engagement after mortality salience: The effects of creativity, conformity, and connectedness on worldview defense. European Journal of Social Psychology, 34, 477-487.

Sedikides, C., Wildshut, T., Routledge, C., \& Arndt, J. (2008). Nostalgia as enabler of self-continuity. In F. Sani (Ed.), Self-continuity. Individual and collective perspectives (pp. 227-239). New York: Psychology Press.

Shneidman, E.S. (1973). Deaths of man. New York: Quadrangle.

Shneidman, E.S. (1976). Current over-view of suicide. In E.S. Shneidman (Ed.), Suicidology: Contemporary developments (pp. 2-12). New York: Grune \& Stratton.

Sircova, A., \& Mitina, O.V. (2008). Vozrastnaya dinamika vremennyh orientacij lichnosti [Age dynamics of personal time perspectives]. Voprosy Psihologii [Psychology Issues], 2, 41-54.

Sokolova, E.T. (1989). Samosoznanie i samootsenka pri anomalijah lichnosti [Selfconsciousness and self-esteem in abnormalities of personality]. Moscow: Moscow State University.

Soubrier, J.-P. (1993). Definitions of suicide. In A.A. Leenaars (Ed.), Suicidology: Essays in honor of Edwin S. Shneidman (pp. 35-41). Northvale, NJ: Aronson.

Tananushko, K.A. (2005). Latinsko-russkiy slovar' [Latin-Russian dictionary]. Minsk: Harvest.

Wildshut, T., Sedikides, C., Arndt, J., \& Routledge, C. (2006). Nostalgia: Content, triggers, functions. Journal of Personality and Social Psychology, 91(5), 975-993.

Wong, P.T. (2007). Meaning management theory and death acceptance. In A. Tomer, G.T. Eliason, \& P.T. Wong (Eds.), Existential and spiritual issues in death attitudes (pp. 65-87). New York: Erlbaum.

Wong, P.T., Reker, G.T., \& Gesser, G. (1994). Death-attitude profile - Revised: A multidimensional measure of attitudes toward death. In R. Neimeyer (Ed.), Death anxiety handbook: Research, instrumentation, and application (pp. 121-148). New York: Taylor and Francis.

Zilboorg, G. (1943). Fear of death. Psychoanalytic Quarterly, 12, 465-475.

Zimbardo, P., \& Boyd, J. (1999). Putting time in perspective: A valid, reliable individual-differences metric. Journal of Personality and Social Psychology, 77(6), 12711288. 